\title{
Sistem Pintu Otomatis Menggunakan E-KTP Berbasis Internet of Things (IoT) pada Kamar Hotel
}

\author{
Yulisman $^{1 *}$, Naziful Iman ${ }^{2}$, Eka Sabna $^{3}$, Hendry Fonda ${ }^{4}$ \\ ${ }^{1,2,4}$ Sistem Informasi, STMIK Hang Tuah Pekanbaru, Pekanbaru, Indonesia \\ ${ }^{3}$ Teknik Informatika, STMIK Hang Tuah Pekanbaru, Pekanbaru, Indonesia \\ Email: ${ }^{1 *}$ yulisman@ @tp.ac.id, ${ }^{2}$ nazifuliman57@email.com, ${ }^{3}$ es3jelita@yahoo.com, ${ }^{4}$ fondaanda@gmail.com
}

\begin{abstract}
The system of opening and closing the hotel room doors is already using RFID but its use is still not optimal because the card used is very expensive and the card used can only be one card for each room, so if the card is lost, you have to re-enter the card id. Therefore, digital electronic technology systems and devices are needed to make it easier to open the door and close the hotel room so that it can facilitate the hotel security system with automatic locks. This system and device uses an E-KTP and an Internet of Thing (IoT)-based Keypad and which functions to control the device using a NodeMCU while for a card reader with an RFID engine. The research method uses a model, namely with a prototype model for making systems and automatic room door locking system tools. The results and conclusions of the manufacture of hotel room automatic door locking systems and devices using an Internet of Thing (IoT)-based E-KTP equipped with a message LCD and keypad as a door opening solution if the RFID machine does not work. The security of hotel guests who stay is more guaranteed and can also make it easier for guests and hotel staff with an automatic hotel room door lock system. The results of the user's assessment of the work of a series of systems and tools to open and lock this automatic hotel room door are very good with a value of $88.7 \%$.
\end{abstract}

Keywords: Arduino Atmega328, E-KTP, Internet of Things (IoT), Hotel Room, Automatic Door System.

\begin{abstract}
ABSTRAK
Sistem pengunci pintu kamar hotel dafam sudah menggunakan RFID namun penggunaanya masih sangat kurang optimal karena kartu yang digunakan biaya nya sangat mahal dan kartu yang digunakan hanya bisa satu kartu untuk masing-masing kamar sehingga apabila kartunya hilang maka harus melakukan penginputan ulang id kartu. Oleh sebab itu dibutuhkan sistem dan perangkat teknologi elektronik digital untuk memudahkan membuka pintu dan menutup kamar hotel sehingga dapat mempermudah sistem pengamanan hotel dengan kunci otomatis. Sistem dan perangkat ini menggunakan E-KTP dan Keypad berbasis Internet of Thing (IoT) dan yang berfungsi untuk mengendalikan alat menggunakan NodeMCU sedangkan untuk pembaca kartu dengan mensin RFID. Metode penelitian dengan sebuah model, yakni dengan model prototype untuk pembuatan sistem dan alat sistem pengunci pintu kamar secara otomatis. Hasil dan kesimpulan dari pembuatan sistem dan alat pengunci pintu otomatis kamar hotel menggunakan E-KTP berbasis Internet of Thing (IoT) yang dilengkapi dengan LCD pemberi pesan dan keypad sebagai solusi pembuka pintu jika mesin RFID tidak berfungsi. Keamanan tamu hotel yang menginap lebih terjamin dan juga dapat memudahkan tamu dan staff hotel dengan sistem pengunci pintu kamar hotel otomatis. Hasil penilaian pengguna terhadap kerja rangkaian sistem dan alat membuka dan mengunci pintu kamar hotel otomatis ini adalah sangat baik dengan nilai $88,7 \%$.
\end{abstract}

Kata Kunci: Arduino Atmega328, E-KTP, Internet of Things (IoT), Kamar Hotel, Sistem Pintu Ototmatis.

\section{Pendahuluan}

terpenting dari sebuah bangunan yang keamanannya sangat perlu diperhatikan dan dengan memperhatikan Sesuai dengan fungsinya, pintu sangat dibutuhkan sistem keamanan pintu yang baik akan atau untuk sebagai perantara atau media penghubung untuk masuk menghindari masuknya seseorang yang ingin dan keluar sebuah ruangan. Pintu juga bagian melakukan upaya pencurian. Sistem keamanan yang 
dipasang pada setiap pintu memiliki perbedaan, jika kartu hilang oleh tamu, pihak hotel harus membuat tergantung dari fungsi ruangan. Ruangan yang kartu dengan biaya yang cukup mahal dan kartu RFID membutuhkan keamanan yang cukup ketat yang juga bisa diduplikat oleh orang yang tidak bertanggung membatasi hak akses ruangan tersebut seperti ruangan jawab untuk merusak dan membobol pintu kamar.

direktur atau ruangan server yang tidak sembarang Dari deskripsi permasalahan di atas peneliti orang dapat memasuki ruangan tersebut. Sebuah mengusulkan suatu metode sistem pengamanan pintu ruangan yang menggunakan sistem pengunci pintu kamar hotel dengan menerapkan teknologi yang lebih yang konvensional, dari segi keamanan kurang efisien, maju supaya dapat membantu pihak hotel dan terutama untuk bangunan yang memiliki ruangan memudahkan serta memberikan kenyamanan kepada dengan banyak pintu dan banyak kunci, selain itu kunci tamu hotel. Penerapan teknologi yang diusulkan konvensional mudah dibuka dan dirusak oleh pencuri peneliti dengan menggunakan kunci pintu kamar yang [1]. Salah satu cara agar keamanan pintu terjamin yaitu otomatis, yakni sistem kunci elektronik otomatis dengan membangun sistem keamanan pintu ruangan dengan tingkat keamanan lebih terjamin, Sehingga dengan mengganti jenis kunci pintu yang masih tidak mudah untuk dirusak dan dibobol oleh pihak atau konvensional (kunci mekanik) dengan kunci elektronik seseorang yg tidak bertanggungjawab. Penelitian ini berbasis teknologi.

juga mengembangkan sistem keamanan pintu kamar Perkembangan teknologi begitu banyak membantu elektronik otomatis berbasis web dengan menggunakan manusia dalam kehidupan sehari-hari dan tanpa sadar E-KTP sebagai kunci untuk membuka dan mengunci kita telah bersandingan aktivitas dengan teknologi yang pintu untuk tamu hotel dan menggunakan numeric semakin maju. Beriringan dengan perkembangan Keypad sebagai kunci darurat untuk akses pintu para teknologi tersebut, peranan dari perangkat komunikasi karyawan hotel, dimana RFID dan Keypad ini nantinya dan kontrol sebagai penunjang dalam peralatan dihubungkan ke microcontroler NodeMCU sebagai elektronika telah menghasilkan metode komunikasi layanan Internet of Things (IoT). Internet of Things ini yang sangat maju seiring dengan perkembangan berfungsi sebagai pemantau dan mengontrol alat dalam teknologi komunikasi yang menjadi perantara manusia jarak yang jauh dengan memanfaatkan konektivitas dan teknologi [2]. Penerapan teknologi pada keamanan pada internet yang tersambung secara terus-menerus pintu merupakan bagian dari teknologi komunikasi, [4]. Fungsi NodeMCU pada sistem dan alat ini akan karena melibatkan pengguna secara langsung seperti melakukan pengiriman data melalui koneksi internet ke teknologi face detection, remote control, finger print, website dengan memanfaatkan SSID WiFi [5], dimana dan masih banyak teknologi bisa terapkan dalam website itu nantinya sebagai pengontrol akses pintu, keamanan pintu. Bicara tentang bangunan yang juga untuk pendaftaran E-KTP tamu hotel, dan memiliki banyak ruangan dan pintu, hotel salah satu pembuatan password untuk Keypad juga akan melalui bangunan atau sarana yang memiliki banyak ruangan website.

dan pintu. Selain itu hotel merupakan sarana tempat Kelebihan dari pengaplikasian alat ini akan tinggal atau singgah beberapa waktu bagi para memberikan pengetahuan baru akan sebuah pintu seseorang yang berpergian jauh dari tempat tinggal, kamar hotel yang bersifat otomatis dengan baik untuk keperluan yang bersifat pribadi seperti menggunakan E-KTP sehingga pihak hotel lebih berwisata maupun untuk keperluan yang berkaitan menghemat biaya untuk kartu RFID karena untuk akses dengan pekerjaan [3].

pintu kamar hotel cukup menggunakan E-KTP dan Setiap hotel tentunya memiliki sarana atau fasilitas keypad, Fungsi keypad untuk pintu darurat apabila Eyang berbeda dan tujuan utama memberikan kenyaman KTP sedang bermasalah. Nantinya alat ini akan dan keamanan bagi para tamu. Salah satu keamanan dirancang menggunakan NodeMCU yang terhubung yang sangat penting dan wajib diperhatikan pihak hotel pada RFID dan Keypad berbasis IoT.

bagi para tamu adalah masalah keamanan pintu Berikut penelitian terkait yang digunakan oleh peneliti ruangan/kamar hotel. Untuk keamanan di kamar hotel sebagai acuan, dimana hasil penelitian menjelaskan hampir semua hotel menggunakan kunci pintu kamar bahwa untuk mencatat kehadiran menggunakan E-KTP dengan kartu Radio Frequency Identification (RFID). berbasis Internet of Thing (IoT) mampu membuat RFID ini sebuah teknologi kartu yang mampu sistem pencatatan kehadiran yang lebih praktis mengidentifikasi berbagai objek dengan memanfaatkan dibandingkan dengan pencatatan kehadiran secara gelombang radio [2]. Termasuk Hotel Dafam dimana manual [6]. Penelitian berikut yang pembahasan dan peneliti meneliti dan sebagai hotel tempat studi kasus tema masih terkait dan mirip, dengan hasil diperoleh penelitian ini. Saat peneliti berkunjung dan mengambil prototype dan aplikasi android bekerja dengan baik data dimana untuk keamanan pintu kamar Hotel Dafam sebagai sistem keamanan menggunakan E-KTP dan dengan akses kunci masuk kamar menggunakan kartu IoT [7]. hasil penelitian yang lainnya menjelaskan RFID. Dengan ruangan/kamar yang begitu banyak, penerapan Internet of Thing dan E-KTP dapat sehingga pihak hotel harus memiliki kartu RFID yang dimanfaatkan sebagai pengaman pada brankas dan banyak untuk membuka akses setiap pintu kamar kartu E-KTP lebih efektif dikarena dibawa setiap hari karena setiap kamar hanya bisa menggunakan satu dan sangat sulit untuk di palsukan atau di duplikasi [8]. kartu RFID untuk satu pintu kamar hotel dan setiap kamar kartu RFID berbeda-beda. Permasalahan lainnya 


\section{Metode Penelitian}

Metode penelitian yang peneliti gunakan dalam penelitian ini dengan mengadopsi sebuah model yakni Prototyping Model. Prototyping Model ini yang akan memandu peneliti dalam setiap tahapan penelitian. Dengan metode atau model prototyping ini akan menghasilkan sebuah prototype sistem/alat sebagai penghubung pembuat/pengembang dan pengguna agar dapat berinteraksi dalam proses aktivitas pembuatan/pengembangan sistem/alat [9]. Berikut skema dari Prototyping Model [10]:

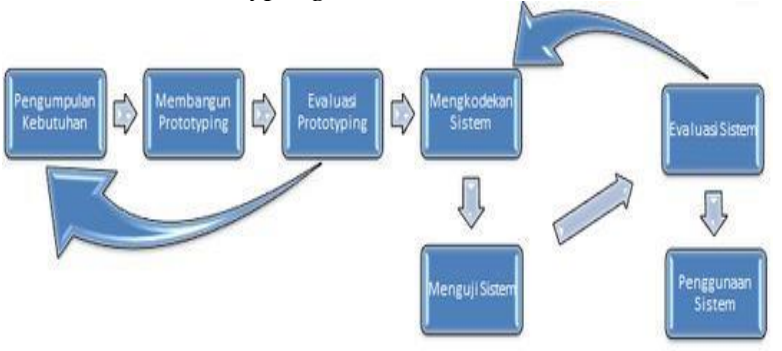

Gambar 1. Prototyping Model

Berdasarkan skema tersebut terdiri dari tujuh tahapan yang dilakukan peneliti dalam membangun sistem dan alat, berikut tahapannya:

a. Pengumpulan Kebutuhan Sistem dan Alat

Pengumpulan kebutuhan atau juga bisa disebut proses pengumpulan data yang merupakan awal dari tahapan penelitian dan tahapan ini dimulai dari mengidentifikasi seluruh perangkat dan permasalahan yang ada ditempat penelitian sekaligus Mengidentifikasi kebutuhan sistem/alat secara garis besar. Pengumpulan kebutuhan ini dilakukan dengan tiga metode, yang pertama metode observasi, yakni peneliti melakukan pengamatan secara langsung pada objek/tempat penelitian, melihat dan datang langsung ke hotel dafam bagaimana tata cara memembuka dan menutup kunci pintu kamar hotel sehingga peneliti dapat mengetahui apa saja yang dibutuhkan dalam perancangan sistem internet of things (IoT) akses kunci pintu menggunakan E-KTP dan Keypad pada hotel. Kedua metode wawancara, yakni metode yang dilakukan secara langsung dengan melakukan tanya jawab dengan pimpinan dan staff, karayawan/ti apa saja kendala dan kekurangan keamanan pintu kamar yang sekarang digunakan. Selanjutnya metode ketiga, metode studi pustaka, yakni melakukan kajian terhadap buku, artikel sumber pustaka lainnya untuk mendukung penelitian ini.

Indetifikasi sistem/alat juga berkaitan dengan identifkasi perangkat keras dan perangkat lunak untuk membangun sistem/alat nanti. Berikut perangkat keras dan lunak yang dibutuhkan untuk membangun sistem/alat Pintu Otomatis Menggunakan E-KTP Berbasis Internet of Things (IoT) pada Kamar Hotel:
Tabel 1. Perangkat Keras yang Dibutuhkan

\begin{tabular}{|c|c|c|c|l|}
\hline No & Hardware & \multicolumn{1}{|c|}{ Spesifikasi } & Jumlah & \multicolumn{1}{|c|}{ Fungsi } \\
\hline 1 & NodeMCU & $\begin{array}{l}\text { Mikrokontroler, } \\
\text { memiliki 14 pin } \\
\text { Input/Output. }\end{array}$ & 1 & $\begin{array}{l}\text { Sebagai otak } \\
\text { pemrosesan }\end{array}$ \\
\hline 2 & RFID & $\begin{array}{l}\text { Tegangan 3V, } \\
\text { memiliki 8pin. }\end{array}$ & 1 & $\begin{array}{l}\text { Sebagai pembaca E- } \\
\text { KTP / Kartu ID }\end{array}$ \\
\hline 3 & Keypad & $\begin{array}{l}\text { Tegangan 3V, } \\
\text { memiliki 8 pin. }\end{array}$ & 1 & $\begin{array}{l}\text { Sebagai } \\
\text { tombol angka }\end{array}$ \\
\hline 4 & Relay & $\begin{array}{l}\text { Tegangan 5V, } \\
\text { memiliki 3 pin. }\end{array}$ & 1 & $\begin{array}{l}\text { Sebagai penetral arus } \\
\text { dari Nodemcu }\end{array}$ \\
\hline 5 & Selenoid & $\begin{array}{l}\text { Tegangan 12V, } \\
\text { memiliki 2 pin. }\end{array}$ & 2 & Sebagai penggerak \\
\hline 7 & Switch & $\begin{array}{l}\text { Tegangan 3V, } \\
\text { memiliki 3 pin. }\end{array}$ & 2 & $\begin{array}{l}\text { Sebagai pemutus dan } \\
\text { penyambung arus }\end{array}$ \\
\hline 8 & Jumper & 5 meter & $\begin{array}{l}\text { Sebagai } \\
\text { penghubung } \\
\text { Nodemcu dengan } \\
\text { Rangkaian }\end{array}$ \\
\hline 9 & Prototype & & $\begin{array}{l}\text { Sebagai penghubung } \\
\text { Arus }\end{array}$ \\
\hline
\end{tabular}

Tabel 2. Perangkat Lunak yang Dibutuhkan

\begin{tabular}{|c|l|c|}
\hline No & & Fungsi \\
\hline 1 & Ardiuno IDE & $\begin{array}{c}\text { Sebagai pembuatan koding untuk } \\
\text { Mikrokontroler Arduino Uno. }\end{array}$ \\
\hline 2 & PHP & Bahasa Pemrogrman untuk Sistem \\
\hline 3 & MySQL & Sebagai Database \\
\hline 4 & Xampp & Aplikasi Tool untuk menjalan MySQL \\
\hline 5 & Notepad ++ & $\begin{array}{r}\text { Sebagai mengkoding sistem dengan bahasa } \\
\text { pemrograman }\end{array}$ \\
\hline 6 & Browser & Sabagai aplikasi menjalankan sistem \\
\hline 7 & Bahasa $C$ & Bahasa pemrograman untuk alat \\
\hline
\end{tabular}

b. Membangun Prototype Sistem dan Alat

Tahap selanjutnya adalah membangun prototype sistem/alat, membangun prototype yang berfokus pada permasalahan dan data yang telah didapat pada pengumpulan kebutuhan pengguna. Membangun prototype ini sama dengan memberikan solusi terhadap masalah yang ada di tempat penelitian. Selanjutnya setelah prototype selesai dikerjakan akan dipresentasikan kepada pengguna untuk dilakukan evaluasi terhadap sistem/alat mengenai kekurangan, error dan bug.

\section{c. Evaluasi Prototype Sistem dan Alat}

Tahap Evaluasi Prototype ini sangat berkaitan dengan tahapan membangun prototype-nya, karena jika sistem/alat ada perbaikan akan kembali ke tahap sebelumnya yakni membangun/perbaikan prototype. Berikut prototype dari sistem dan alat:

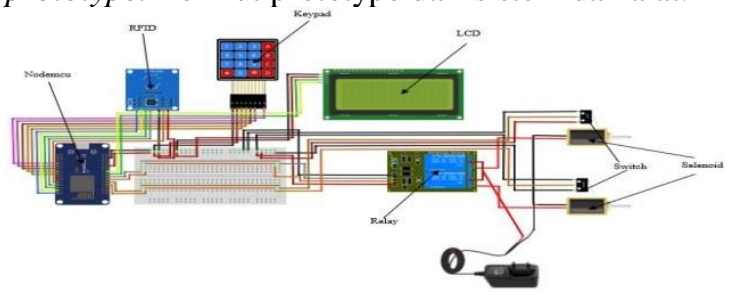

Gambar 2. Prototype alat pengunci pintu otomatis

DOI: $10.54259 /$ satesi.v1i2.60

Lisensi: Creative Commons Attribution 4.0 International (CC BY 4.0) 
d. Mengkodekan Sistem dan Alat

Tahapan mengkodekan Sistem/alat yakni mengkodekan sistem/alat dengan menggunakan bahasa pemrograman. Bahasa pemrograman yang digunakan untuk membangun rangkaian alat adalah bahasa C, Bahasa ini dibangun oleh DennisRitchie dari AT\&T Bell Labs pada tahun 1972. Bahasa C khusus dibuat untuk pemrograman secara umum dan menjadi bahasa yang paling luas digunakan di seluruh dunia. Kompiler $\mathrm{C}$ dapat digunakan hampir di seluruh arsitektur komputer dan sistem operasi. Desain bahasa $\mathrm{C}$ menyediakan compiler yang memberikan akses level rendah ke memori sehingga hasil kompilasi relatif lebih efisien untuk dipindahkan ke dalam bahasa mesin [11]. Arduino $I D E$ sebagaai aplikasi pendukung yang digunakan dalam membangun sistem/alat. Arduino IDE adalah perangkat lunak yang bersifat Open Source dan dapat di download secara gratis dan terbuka di www.arduino.cc. IDE (Integrated Development Environment) berarti bentuk alat pengembangan program yang ter-intergrasi sehingga berbagai keperluan disiapkan dan dijelaskan dalam bentuk tampilan berbasis menu. Ini berjalan pada Windows, Mac OS X, dan linux [12].

e. Pengujian Sistem dan Alat

Selanjutnya pengujian terhadap sistem dan alat yang telah dibangun. Pengujian dilakukan dengan menguji sistem/alat secara keseluruhan dengan menggunakan metode pengujian black box testing. Pengujian black box ini yakni dimana peneliti mengamati dengan seksama secara fungsi, konektifitas dan notifikasi yang dihasilkan sistem dan alat yang telah dibangun [13]. Adapun pengujian secara fungsional dilakukan terhadap beberapa sensor

1) Pengujian KTP/RFID

Pengujian black box pertama diawali dengan menggunakan KTP dan Kartu RFID. Ketika menempelkan KTP / RFID yang sudah didaftarkan yang terbaca oleh Sensor RFID maka pintu terbuka dan Ketika menempelkan KTP / RFID yang belum didaftarkan terbaca Sensor RFID maka pintu tidak terbuka. Sensor RFID akan mengirim data ke mikrokontroler NodeMCU, seperti yang terlihat pada tabel berikut:

Tabel 3. Pengujian Black Box 1 untuk KTP/RFD

\begin{tabular}{|c|c|c|c|c|c|}
\hline $\mathrm{No}$ & $\begin{array}{c}\text { Skenario } \\
\text { Pengujian }\end{array}$ & $\begin{array}{c}\text { Tes Case } \\
\text { Alat }\end{array}$ & Pintu & $\begin{array}{c}\text { Tes Case } \\
\text { Sistem }\end{array}$ & $\begin{array}{l}\text { Kesim } \\
\text { pulan }\end{array}$ \\
\hline 1 & $\begin{array}{l}\text { Menempelkan } \\
\text { KTP / RFID } \\
\text { yang sudah } \\
\text { didaftarkan }\end{array}$ & & Terbuka & $=$ & Valid \\
\hline 2 & $\begin{array}{l}\text { Menempelkan } \\
\text { KTP / RFID } \\
\text { yang belum } \\
\text { didaftarkan }\end{array}$ & & $\begin{array}{c}\text { Tidak } \\
\text { Terbuka }\end{array}$ & $\begin{array}{l} \\
= \\
= \\
=\end{array}$ & Valid \\
\hline
\end{tabular}

\section{2) Pengujian Keypad}

Pengujian dengan menekan Keypad. Ketika memasukkan key yang sudah ditetapkan yang terbaca oleh Keypad maka pintu terbuka dan ketika tidak memasukkan key belum didaftarkan yang terbaca oleh Keypad maka pintu tidak terbuka. Keypad akan mengirim data ke mikrokontroler Nodemcu, seperti yang telihat pada tabel berikut:

Tabel 4. Pengujian untuk Keypad

\begin{tabular}{|c|c|c|c|c|}
\hline No & $\begin{array}{c}\text { Skenario } \\
\text { Pengujian }\end{array}$ & Tes Case Alat & Pintu & $\begin{array}{l}\text { Kesim } \\
\text { pulan }\end{array}$ \\
\hline 1 & $\begin{array}{c}\text { Memasukkan } \\
\text { key yang sudah } \\
\text { ditetapkan }\end{array}$ & & Terbuka & Valid \\
\hline 2 & $\begin{array}{c}\text { Tidak } \\
\text { memasukkan key }\end{array}$ & & $\begin{array}{c}\text { Tidak } \\
\text { Terbuka }\end{array}$ & Valid \\
\hline
\end{tabular}

\section{3) Pengujian Akses Sistem}

Ketika KTP / RFID yang sudah didaftarkan yang terbaca oleh RFID maka Akses Sistem Diterima dan Ketika KTP / RFID yang belum didaftarkan yang terbaca oleh RFID maka Akses Sistem Ditolak. Hasil dari pengujian tersebut dapat dilihat pada tabel 5 berikut:

Tabel 5. Pengujian untuk Akses Sistem

\begin{tabular}{|c|c|c|c|c|}
\hline No & $\begin{array}{c}\text { Skenario } \\
\text { Pengujian }\end{array}$ & Tes Case Sistem & \begin{tabular}{l|} 
Akses \\
Sistem
\end{tabular} & $\begin{array}{l}\text { Kesim } \\
\text { pulan }\end{array}$ \\
\hline 1 & $\begin{array}{l}\text { KTP / RFID } \\
\text { yang sudah } \\
\text { didaftarkan }\end{array}$ & 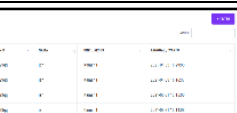 & Diterima & Valid \\
\hline 2 & $\begin{array}{l}\text { KTP / RFID } \\
\text { yang belum } \\
\text { didaftarkan }\end{array}$ & 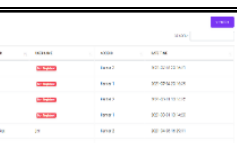 & Ditolak & Valid \\
\hline
\end{tabular}

f. Evaluasi Sistem dan Alat

Evaluasi sangat bergantung pada pengujian sistem dan alat, karena dengan hasil pengujian sistem dan alat akan menjadi acuan apakah sistem dan alat sudah sesuai dengan kebutuhan pengguna atau masih kekurangan seperti tidak berfungsi suatu modul sistem dan alat dengan baik dan masih ada bug pada koding sistem dan alat. Penelitian melakukan beberapa pengujian ketika membangun sistem dan alat sehingga pada pengujian ini tahap akhir dengan pengguna, sistem dan alat sesuai dengan harapan pengguna dan tidak ada kesalahan baik pada modul atau koding sistem dan alat. Berikut adalah alur/flowchart dari penggunaan sistem dan alat penggunsi otomatis dengan E-KTP dan Keypad berbasis Internet of Things (IoT): 


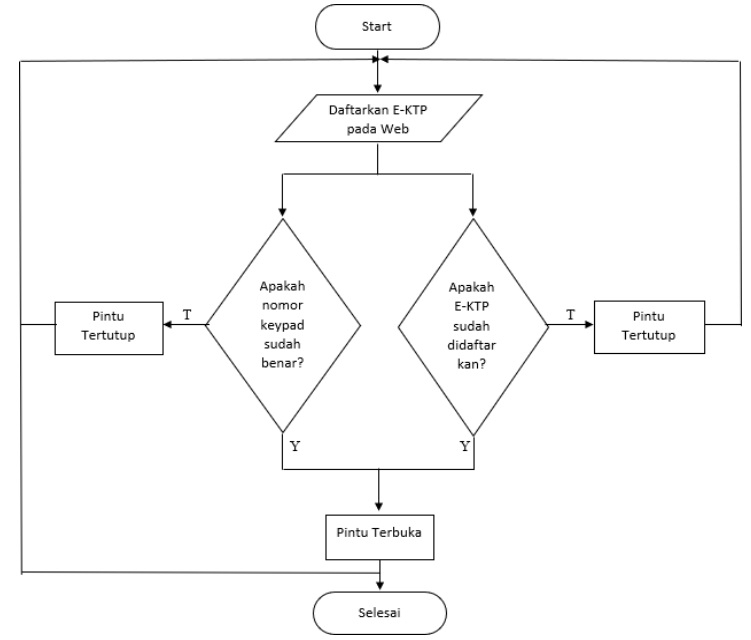

Gambar 3. Flowchart/Alur Penggunaan Sistem dan Alat

Setelah pengujian dilakukan pengguna minta untuk memberikan penilaian terhadap sistem dan alat. Pengguna terdiri dari Pimpinan, Manajer, Resepsionis, dan OB, sehingga peneliti mendapatkan pengguna 9 orang sebagai perwakilan memberikan penilaian terhadap kalayakan sistem dan alat. Penggujian dan penilaian dan kelayakan sistem dan alat yang diimplemestasi pada sistem akses pintu otomatis menggunakan e-KTP dan keypad untuk mengkases pintu di kamar hotel diatas, maka dapat diambil kesimpulan kelengkapan fitur alat rata- rata keseluruhan pengujian alat yaitu $88.7 \%$, ini berarti bahwa sistem berfungsi dengan sangat baik.

g. Penggunaan Sistem dan Alat

Tahap ini adalah implementasi sistem dan alat oleh pengguna, tidak semua kamar hotel yang diimplementasikan dengan sistem dan alat penggunci Otomatis dengan E-KTP dan Keypad berbasis Internet of Things (IoT), pengguna memilih dua kamar saja sebagai percontohan.

\section{Hasil dan Pembahasan}

Setelah berbagai tahapan yang dilewati kita masuk ke hasil dan pembahasan, dimana hasil dan pembahasan ini menampilkan sistem dan alat yang telah selesai dibangun dan siap diimplementasikan ke tempat penelitian. Berikut adalah tampilan dari sistem dan alat yang telah di bangun:

a. Tampilan Sistem Pengunci Pintu Kamar Hotel Otomatis

Tampilan sistem ini adalah tampilan dari website untuk koneksi ke alat pengunci pintu kamar secara otomatis. Dimana setiap data E-KTP tamu hotel akan direkam dengan sistem ini.

1) Tampilan login sistem

Tampilan berikut adalah tampilan awal ketika user (kasir) ingin masuk dan melakukan perekaman EKTP tamu ke sistem.

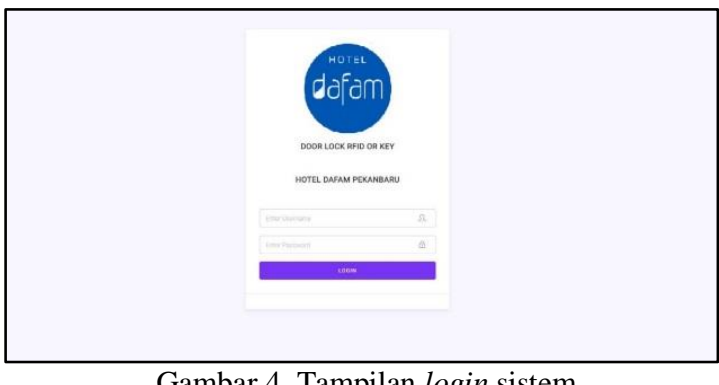

Gambar 4. Tampilan login sistem

2) Tampilan halaman utama

Pada tampilan halaman utama ini ada beberapa menu yang bisa di akses oleh user (kasir) untuk proses perekaman E-KTP tamu hotel. Berikut tampilannya:

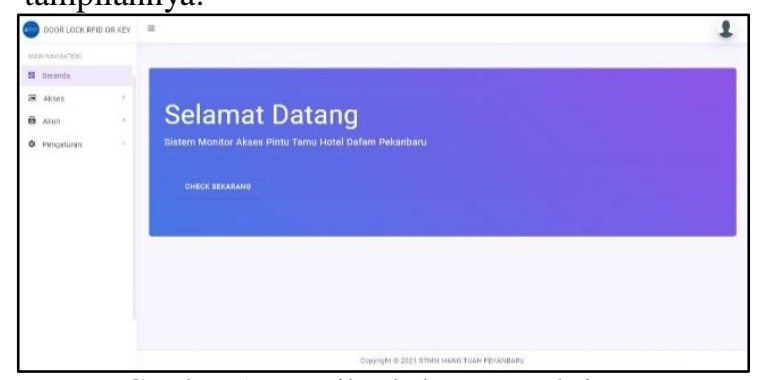

Gambar 5. Tampilan halaman awal sistem

3) Tampilan akses tamu

Pada tampilan ini kasir bisa melihat akses tamu yang aktif dan sudah cekin untuk menginap.

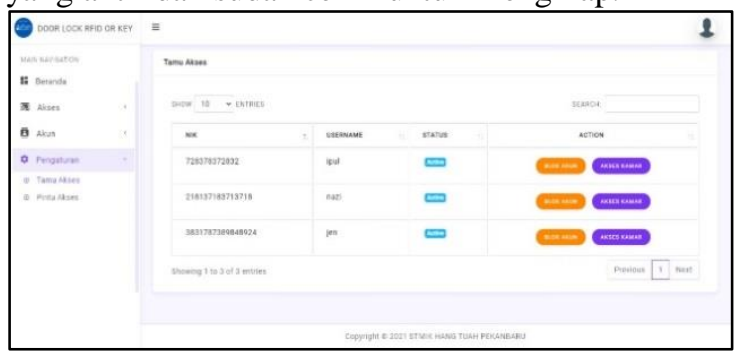

Gambar 6. Tampilan halaman awal sistem

4) Tampilan akses tamu yang diterima

Tampilan berikut adalah tampilan data tamu yang akses E-KTP nya diterima atau terdeteksi oleh sistem dan alat.

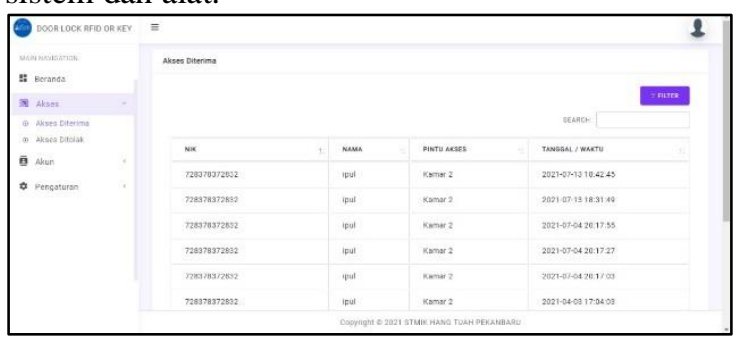

Gambar 7. Tampilan akses tamu yang diterima

5) Tampilan akses tamu yang ditolak

Tampilan berikut adalah tampilan data tamu yang akses E-KTP nya ditolak, artinya data E-KTP tamu belum terekam oleh sistem dan alat tidak mendeteksi E-KTP tersebut. 


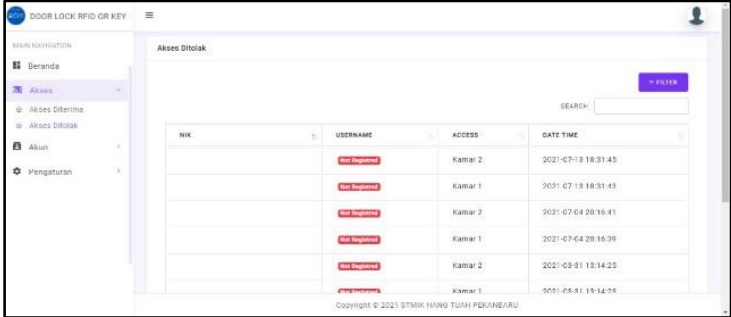

Gambar 8. Tampilan akses tamu yang ditolak

6) Tampilan Menu Admin

Admin adalah yang mengatur sistem dan alat secara keseluruhan yang mempunyai akss khusus, berikut tampilan dari menu Admin:

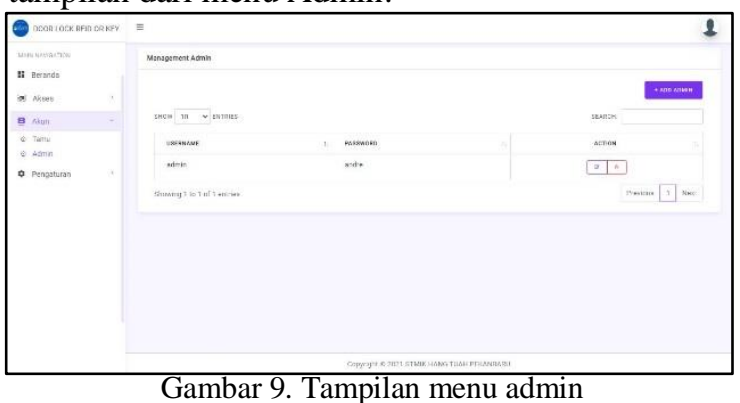

7) Tampilan Akses Pintu

Tampilan berikut adalah data pintu kamar yang telah terdaftar dan aksesnya masuk pintu yang telah diterima oleh sistem dan alat.

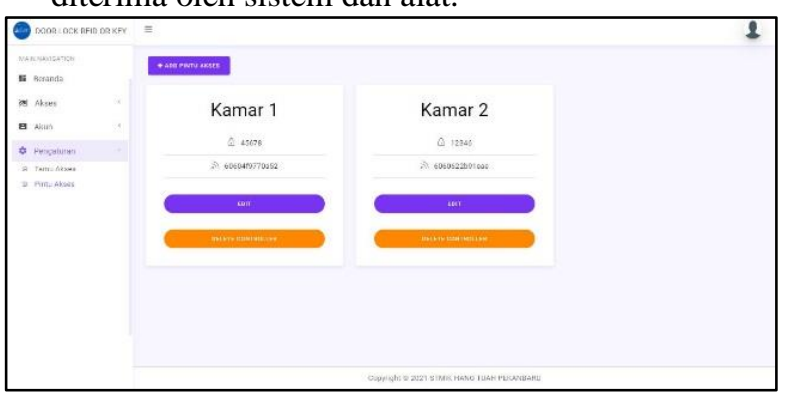

Gambar 10. Tampilan akses pintu

b. Raangkaian Alat Pengunci Pintu Otomatis dengan E-KTP berbasis IoT

Berikut ini adalah rangkaian alat pangunci otomatis dengan E-KTP pada kamar hotel berbasis Internet of Things (IoT). Alur kerja rangkaian alat ini dengan menempelkan E-KTP yang sudah didaftarkan yang terbaca oleh Sensor E-KTP maka pintu terbuka dan dengan menempelkan E-KTP yang belum didaftarkan terbaca Sensor E-KTP maka pintu tidak terbuka. Sensor E-KTP akan mengirim data ke mikrokontroler NodeMCU. Berikut jika sensor E-KTP tidak befungsi staff hotel bisa dengan memasukkan key yang sudah ditetapkan yang terbaca oleh Keypad maka pintu terbuka dan jika tidak memasukkan key belum didaftarkan yang terbaca oleh Keypad maka pintu tidak terbuka. Keypad akan mengirim data ke mikrokontroler NodeMCU.

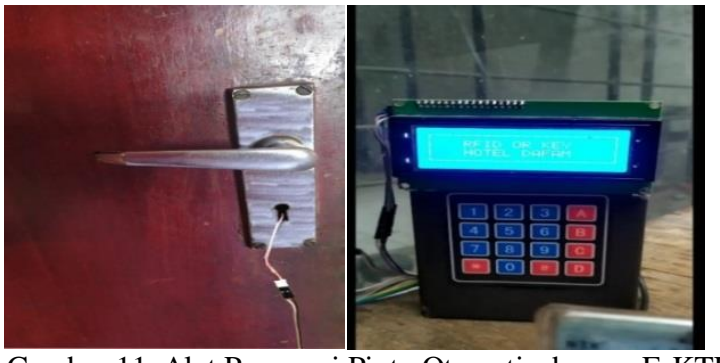

Gambar 11. Alat Pengunci Pintu Otomatis dengan E-KTP berbasis IoT

\section{Kesimpulan}

Sistem dan alat telah berhasil dibangun yang melewati beberapa tahapan mulai dari pengumpulan data sampai dengan pengujian dan implemetasi sistem dan alat. Berdasarkan hal tersebut di dapat kesimpulan bahwa rangkaian sistem dan alat pengunci pintu otomatis kamar hotel menggunakan E-KTP berbasis Internet of Thing (IoT) yang dilengkapi dengan LCD dan keypad dapat memudahkan dan membantu tamu dan staff hotel dalam membuka dan menutup pintu kamar hotel. Keamanan tamu hotel lebih terjamin dengan sistem dan alat pengunci pintu otomatis kamar hotel menggunakan E-KTP tamu sendiri, dan sistem dan alat dapat bekerja dengan sangat baik dengan hasil penilaian yakni $88.7 \%$.

Saran untuk tempat penelitian agar untuk selanjutnya diharapkan dapat mengembangkan pengendalian Sistem pengontrolan keamanan pintu kamar hotel berbasis Android atau sistem $Q R$ code pada tiket masuk.

\section{Referensi}

[1] T. Novianti and G. F. A. Winagi, "Rancang Bangun Pintu Otomatis dengan Menggunakan RFID," J. Tek. Elektro dan Komput. TRIAC, vol. 6, no. 1, pp. 1-6, 2019, doi: 10.21107/triac.v6i1.4878.

2] A. A. Sofyan, P. Puspitorini, and D. Baehaki, "Sistem Keamanan Pengendali Pintu Otomatis Berbasis Radio Frequency Identification (RFID) Dengan Arduino Uno R3," J. Sisfotek Glob., vol. 7, no. 1, pp. 35-41, 2017, doi: 10.38101/sisfotek.v7i1.116.

[3] A. S. Akbar, "Rancang Bangun Sistem Informasi Administrasi Hotel Dengan Metode Extreme Programming," J. Disprotek, vol. 8, no. 2, pp. 26-41, 2017, doi: 10.34001/jdpt.v8i2.540.

[4] K. H, H. Subrata, Rosalia, and F. Gozali, "Sistem Keamanan Ruangan Berbasis Internet Of Things Dengan Menggunakan Aplikasi Android," TESLA J. Tek. Elektro, vol. 20, no. 2, pp. 127-134, 2019, doi: 10.24912/tesla.v20i2.2989.

[5] F. H. A. Mubarok and M. Subali, "Sistem Keamanan Pintu Portal Pada Perumahan Dengan Rfid Menggunakan Nodemcu," Semin. Nas. Teknol. Inf. dan Komun. STI\&K, vol. 4, no. 1, 2020, doi: 10.32409/jikstik.4.1.320.

[6] A. Sopa, H. M. Saputra, and A. Nurhakim, "Sistem Kehadiran Menggunakan RFID pada E-KTP Berbasis Internet of Things Attendance System using RFID on E-KTP Based on Internet of Things," in Senter 2019, 2019, no. November, pp. 412-418.

7] A. A. Najib, R. Munadi, and N. B. A. Karna, "Security system with RFID control using E-KTP and internet of things," Bull. Electr. Eng. Informatics, vol. 10, no. 3, pp. 1436-1445, 2021, doi: 10.11591/eei.v10i3.2834.

[8] A. T. Mahesa, H. Rahmawan, A. Rinharsah, and S. Arifin, "Sistem Keamanan Brankas Berbasis Kartu Rfid E-Ktp," $J$. 
Teknol. dan Manaj. Inform., vol. 5, no. 1, 2019, doi: 10.26905/jtmi.v5i1.3105.

[9] D. Purnomo, "Model Prototyping Pada Pengembangan Sistem Informasi," J I M P - J. Inform. Merdeka Pasuruan, vol. 2, no. 2, pp. 54-61, 2017, doi: 10.37438/jimp.v2i2.67.

[10] Yulisman and Serdiansah, "Aplikasi Pengenalan Kebudayaan Provinsi Riau Berbasis Android," J. Teknol. Sist. Inf. dan Apl., vol. 2, no. 3, pp. 79-90, 2019, doi: http://dx.doi.org/10.32493/jtsi.v2i3.3294.

[11]M. T. Pratama, "Evolusi Bahasa Pemrograman (Evolution Of
Programming Language)," J. Comput. Bisnis, vol. 8, no. 1, pp. 35-42, 2014, [Online]. Available: http://jurnal.stmikmi.ac.id/index.php/jcb/article/view/112.

[12]A. Kadir, Pemrograman Arduino \& Android Menggunakan App Inventor. Jakarta: Elex Media Komputindo, 2017.

13]F. E. Prasetiyo and D. Setiyadi, "Sistem Pendeteksi Ancaman Keamanan Rumah Dengan Menggunakan Telegram Berbasis Internet Of Things," J. ICT Inf. Commun. Technol., vol. 20, no. 1, pp. 127-132, 2021, doi: 10.36054/jict-ikmi.v20i1.340. 